Requests for reprints should be addressed to Dr T D R Hockaday, Radcliffe Infirmary, Oxford.

\section{References}

1 McLaren, B H, Burden, A C, and Moorhead, P J, British Medical fournal, $1977,2,291$.

2 Harris, H W, Knight, R A, and Selin, M J, American Review of Tuberculosis, $1958,78,944$

${ }^{3}$ Evans, D A P, fournal of Medical Genetics, 1969, 6, 405.

4 Evans, D A P, and White, T A, fournal of Laboratory and Clinical Medicine, 1964, 63, 394.

5 Mourant, A E, Kopec, A C, and Domaniewska-Sobczak, K, in The Distribution of the Human Blood Groups and other Polymorphisms, p 45. London, Oxford University Press, 1976.

${ }^{6}$ Mattila, M J, and Tiitinen, H, Annales Medicinae Experimentalis et Biologiae Fenniae, 1967, 45, 423.
${ }^{7}$ Hockaday, T D R, et al, British fournal of Nutrition. In press.

Technicon AutoAnalyzer Manual. Glucose oxidase (gum guiac) method.

${ }^{9}$ Soeldner, J S, and Slone, D, Diabetes, 1965, 14, 771.

1" Porte, D, jun, Bagdade, J D, and Bierman, E L, Advances in Metabolic Disurders, 1970, Suppl No 1, p 191.

${ }^{11}$ Jenne, J W, and Boyer, P D, Biochimica et Biophysica Acta, 1963, 65, 121. 12 Nikkila, E A, and Kerppola, W, Scandinavian fournal of Clinical and Laboratory Investigation, 1957, 9, 105.

${ }^{13}$ Szorady, I, Pharmacogenetics. Budapest, Akademiai Kiado, 1973.

${ }^{14}$ Lindsten, J, et al, Clinical Genetics, 1976, 10, 125.

${ }_{15}$ Cerasi, E, and Luft, R, Lancet, 1963, 2, 1359.

${ }^{16}$ Jenne, J W, fournal of Clinical Investigation, 1965, 44, 1992.

17 Ashcroft, S J H, and Crossley, J R, Diabetologia, 1975, 11, 279.

${ }_{18}$ Wilcox, R G, and Mitchell, J R A, British Medical fournal, 1977, 2, 547.

19 Cowan, G O, Das, K M, and Eastwood, M A, British Medical fournal, $1977,2,1057$.

2" Evans, D A P, Annals of the New York Academy of Sciences, 1968, 151, 723.

(Accepted 10 November 1977)

\title{
Thyroid function in lung cancer
}

\author{
J G RATCLIFFE, B H R STACK, R W BURT, W A RATCLIFFE, W G S SPILG, J CUTHBERT, \\ R S KENNEDY
}

British Medical fournal, 1978, 1, 210-212

\section{Summary and conclusions}

Thyroid function was assessed at the time of initial diagnosis in 204 patients with lung cancer and compared with that of age and sex-matched patients with nonmalignant lung disease. Abnormalities in thyroid function were found in 67 patients $(33 \%)$. The most prevalent abnormality was a low $\mathrm{T} 3$ concentration; this was not associated with other clinical or biochemical evidence of hypothyroidism, but the short-term prognosis of these patients was worse than that of matched patients with lung cancer having normal T3 concentrations. Primary hypothyroidism occurred in three patients, low T4 concentrations and free thyroxine index (FTI) with normal thyrotrophin (TSH) concentrations in four patients, and moderately raised TSH with normal thyroid hormone concentrations in six patients; nine patients had a raised FTI with or without raised $T 4$ concentration as the sole abnormality.

Overall, the pattern of thyroid hormone metabolism in lung cancer was a tendency towards reduced T3

Radioimmunoassay Unit, Stobhill Hospital, Glasgow G21 3UW

J G RATCLIFFE, DM, MRCPATH, consultant

R W BURT, BSC, biochemist

W A RATCLIFFE, PHD, biochemist

Western Infirmary and Chest Clinic, Knightswood Hospital, Glasgow G13 2XG

B H R STACK, MD, MRCP, consultant

Department of Pathology, Victoria Infirmary, Glasgow G42 9TY W G S SPILG, MB, MRCPATH, consultant

Chest Clinic, Florence Street, Glasgow

J CUTHBERT, MD, FRCSGLAs, consultant

Chest Clinic, Belvidere Hospital, Glasgow G31 4PG

R S KENNEDY, FRCP, DPH, consultant concentrations with significantly increased $\mathrm{T} 4 \mathrm{~T} 3$ ratios and modestly increased $3,3^{\prime}, 5^{\prime}$-triiodothyronine (rT3) concentrations. The altered $\mathrm{T} 4 \mathrm{~T} 3$ ratio was particularly noticeable in patients with anaplastic tumours of small ("oat cell") and large cell types, but was not apparently related to detectable extrathoracic metastases.

These data suggest that thyroid hormone metabolism is altered in patients with lung cancer by decreased 5 -monodeiodination of $T 4$. The resulting low $T 3$ concentrations and altered $\mathrm{T} 4 / \mathrm{T} 3$ ratio may be partly responsible for the reduced ratio of androsterone to aetiocholanolone observed in lung cancer, which is known to be a poor prognostic sign.

\section{Introduction}

A relationship between thyroid function and cancer has been postulated since Beatson ${ }^{1}$ successfully treated a woman with metastatic breast carcinoma by oophorectomy combined with thyroid extract. Considerable indirect evidence suggests an interaction between thyroid function and malignant disease, particularly breast carcinoma. ${ }^{2-5}$ The association of thyroid disease with lung cancer, however, has only occasionally been reported. Hyperthyroidism in this condition was described by de Gennes $e t$ al $^{6}$ and Rassam and Anderson ${ }^{7}$ (one patient is reported to have shown direct evidence of inappropriate $\mathrm{TSH}$ production by the tumour). We have compared thyroid function in patients with lung cancer at the time of initial diagnosis with that in ageand sex-matched patients with non-malignant lung disease in an attempt to define the presence, nature, and possible mechanism of any abnormalities.

\section{Methods}

PATIENTS STUDIED

Lung cancer-Serum samples for thyroid function studies were taken from 204 patients with lung cancer-166 men (aged 26-85, mean 63) and 38 women (aged 45-82, mean 61)-about.the time they were first seen at one of three specialist chest clinics between 1 April 1974 and 1 December 1975. Diagnosis was based on clinical, radio- 
logical, or bronchoscopic criteria, or a combination of these. Malignancy was confirmed histologically in 118 and cytologically in 15 patients $\left(64^{\circ}{ }_{0}\right)$. We did not attempt any detailed staging of the disease apart from assessing whether extrathoracic metastases were present. Those with known thyroid disorders or taking drugs known to affect thyroid hormone metabolism were excluded. The patients were followed to June 1976-that is, for at least six months and at most 26. Histological appearances were reviewed in an unselected group of 55 patients and classified according to the World Health Organisation criteria* by a pathologist unaware of the clinical or laboratory data.

Control patients-Serum samples from 70 clinically euthyroid patients attending one of the chest clinics with non-malignant lung disease (mainly chronic bronchitis and tuberculosis) were taken for thyroid function studies. These patients were age- and sex-matched with the 55 lung cancer patients who were studied histologically. As with the lung cancer group, patients with thyroid disease or taking drugs known to affect thyroid hormone metabolism were excluded.

\section{LABORATORY METHODS}

Total thyroxine (T4), triiodothyronine (T3), reverse triiodothyronine (rT3), and thyroid-stimulating hormone (TSH) were measured by double antibody radioimmunoassays in unextracted serum. ${ }^{9-11}$ The free thyroxine index (FTI) was calculated from the ratio total T4 : thyroid hormone uptake test $\times 100$. Thyopac 3 (Radiochemical Centre, Amersham) was used for the uptake test.

The statistical significance of differences between groups was determined by the Student's $t$ test.

\section{Results}

Thyroid function in total group of lung cancer patients-The mean serum T3 and T4 concentrations and FTI (see figure) in the patients with the lung cancer were within the reference ranges established for euthyroid hospitalised patients, which are similar to the absolute ranges for the control patients. Mean T4 and rT3 concentrations and FTI were slightly but not significantly higher than in the control patients, whereas the mean T3 concentration was significantly lower $(\mathbf{P}<0.001)$. Forty-five patients $\left(23^{\circ}\right)$ had T3 values below the control range as the sole abnormality. Other abnormal patterns were observed in 22 patients $\left(11^{\circ}{ }_{0}\right)$ (table I). Three patients $\left(1.5^{\circ}{ }_{0}\right)$ had unequivocal primary hypothyroidism. Of the 19 clinically euthyroid patients, four (cases 4-7) had low T4 and FTI concentrations (with or without low T3), with TSH concentrations undetectable in three-that is, the biochemical pattern of secondary hypothyroidism-and high normal in one. Six patients (cases $8-13)\left(3^{\circ}\right)$, had a moderately raised TSH

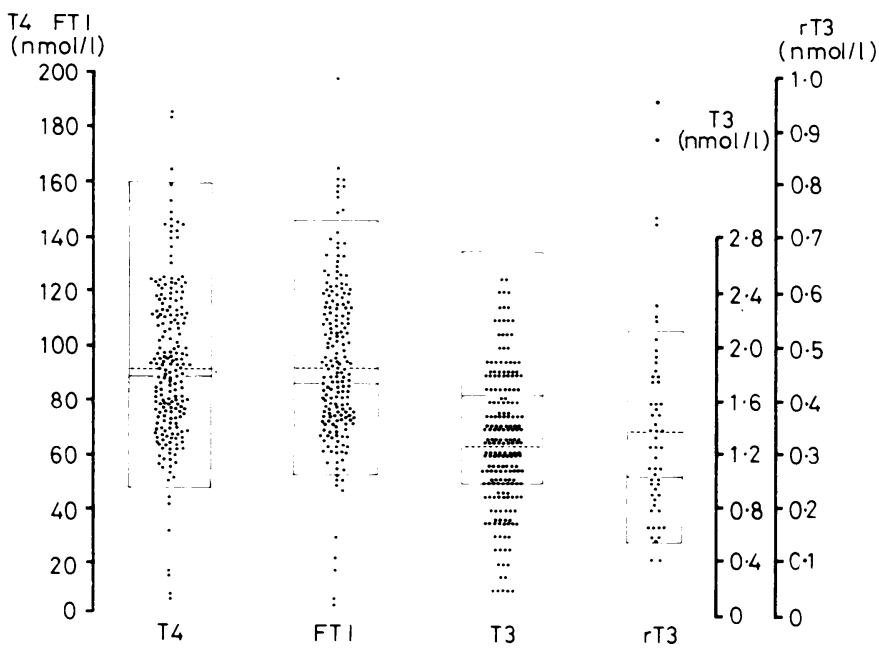

$\mathrm{T} 4, \mathrm{~T} 3$, and $\mathrm{rT} 3$ concentrations and FTI in patients with lung cancer. All 204 patients had T4, T3, and FTI tests. Reverse T3 levels were determined in 55 of these patients. In each case the mean value for the lung cancer patients is indicated by an interrupted horizontal line. The absolute ranges of values found in 70 control patients with non-malignant lung disease are indicated by the solid boxes and the means by the solid horizontal lines.
TABLE I-Abnormal thyroid hormone levels in patients with lung cancer

\begin{tabular}{|c|c|c|c|c|c|c|}
\hline $\begin{array}{l}\text { Patient } \\
\text { No }\end{array}$ & $\begin{array}{c}\text { Age } \\
\text { and sex }\end{array}$ & $\begin{array}{c}\mathrm{T} 4 \\
(\mathrm{nmol} 1)\end{array}$ & FTI & $\begin{array}{c}\text { T3 } \\
(\mathrm{nmol} \mathrm{l})\end{array}$ & $\begin{array}{l}\text { TSH } \\
(\mathrm{mU} 1)\end{array}$ & Comment \\
\hline 1 & $60 \mathrm{~F}$ & 32 & 29 & $0 \cdot 9$ & $>50$ & 1 hypothyroid \\
\hline 2 & $73 \mathrm{~F}$ & 8 & 6 & 0.4 & $>50$ & 1 hypothyroid \\
\hline 3 & $61 \mathrm{~F}$ & 7 & 5 & 0.9 & $>50$ & 1 hypothyroid \\
\hline $\begin{array}{l}4 \\
5\end{array}$ & $\begin{array}{l}77 \mathrm{M} \\
65 \mathrm{M}\end{array}$ & $\begin{array}{r}<19 \\
16\end{array}$ & $\begin{array}{r}<22 \\
17\end{array}$ & $\begin{array}{l}0.2 \\
1.6\end{array}$ & $\begin{array}{l}<2 \cdot 7 \\
<2 \cdot 0\end{array}$ & Dead (1 month) \\
\hline $\begin{array}{l}6 \\
7\end{array}$ & $\begin{array}{l}55 \mathrm{M} \\
80 \mathrm{~F}\end{array}$ & $\begin{array}{l}41 \\
44\end{array}$ & $\begin{array}{l}47 \\
53\end{array}$ & $\begin{array}{l}1.6 \\
0.2\end{array}$ & $\begin{array}{r}<2.0 \\
8.3\end{array}$ & $\begin{array}{l}\text { Dead ( } 7 \text { months }) \\
\text { On prednisolone } \\
\text { Dead ( } 10 \text { days })\end{array}$ \\
\hline $\begin{array}{r}8 \\
9 \\
10 \\
11 \\
12 \\
13\end{array}$ & $\begin{array}{l}68 M \\
55 M \\
62 M \\
61 \mathrm{~F} \\
49 \mathrm{M} \\
79 \mathrm{M}\end{array}$ & $\begin{array}{l}61 \\
97 \\
94 \\
75 \\
80 \\
80\end{array}$ & $\begin{array}{r}66 \\
115 \\
108 \\
92 \\
86\end{array}$ & $\begin{array}{l}0.9 \\
1.4 \\
1.4 \\
1.4 \\
1.8 \\
1.0\end{array}$ & $\begin{array}{l}10 \cdot 1 \\
16.8 \\
11.3 \\
17 \cdot 8 \\
10.3 \\
26 \cdot 0\end{array}$ & $\begin{array}{l}\text { Dead ( } 3 \text { months) } \\
\text { Dead (1 month) } \\
\text { Dead (4 months) } \\
\text { Dead (12 months) } \\
\text { Alive ( } 24 \text { months) } \\
\text { Dead (5 months) }\end{array}$ \\
\hline $\begin{array}{l}14 \\
15 \\
16 \\
17 \\
18 \\
19 \\
20 \\
21 \\
22\end{array}$ & $\begin{array}{l}60 \mathrm{M} \\
72 \mathrm{~F} \\
58 \mathrm{~F} \\
61 \mathrm{~F} \\
61 \mathrm{~F} \\
82 \mathrm{~F} \\
68 \mathrm{~F} \\
54 \mathrm{~F} \\
67 \mathrm{M}\end{array}$ & $\begin{array}{l}184 \\
186 \\
165 \\
146 \\
116 \\
144 \\
149 \\
159 \\
144\end{array}$ & $\begin{array}{l}158 \\
155 \\
149 \\
162 \\
157 \\
165 \\
159 \\
199 \\
150\end{array}$ & $\begin{array}{l}1.7 \\
1.5 \\
2.0 \\
1.6 \\
1.3 \\
1.1 \\
1.8 \\
1.8 \\
1.1\end{array}$ & $\begin{array}{r}2 \cdot 6 \\
5 \cdot 1 \\
4 \cdot 3 \\
2 \cdot 7 \\
3 \cdot 7 \\
6 \cdot 4 \\
5 \cdot 8 \\
<2 \cdot 0 \\
6 \cdot 4\end{array}$ & $\begin{array}{l}\text { Dead (1 week) } \\
\text { Dead (2 weeks) } \\
\text { Dead ( } 7 \text { months) } \\
\text { Dead ( } 3 \text { months) } \\
\text { Dead (1 week) } \\
\text { Dead (1 month) } \\
\text { Dead (2 weeks) } \\
\text { Dead (18 months) } \\
\text { Dead (4 days) }\end{array}$ \\
\hline
\end{tabular}

Conversion: SI to traditional units-T3: $1 \mathrm{nmol} \mathrm{l}=0.065 \mu \mathrm{g} 100 \mathrm{ml}$. T4: $1 \mathrm{nmol} \mathrm{l}=$ $0.078 \mu \mathrm{g} 100 \mathrm{ml}$.

concentration as the sole abnormality-that is, the biochemical pattern of subclinical hypothyroidism-and nine patients (cases $14-22)(4 \%)$ had a raised FTI with a normal or slightly raised T4 concentration. No patient had a raised $\mathrm{T} 3$ concentration.

Characteristics of patients with low T3 levels-Subnormal T3 concentrations were the sole abnormality in $23 \%$ of the lung cancer patients. If the three patients with primary hypothyroidism are excluded, this group had a significantly lower T4 concentration and FTI than age and sex-matched lung cancer patients with normal T3 concentrations (table II). Short-term survival was poorer in the lowT3 group than in the age- and sex-matched lung cancer patients with normal T3 concentrations, 22 out of $45(49 \%)$ compared with only $12\left(27^{\circ}\right)$ of the latter dying within six months.

Relationship of thyroid function to tumour histology-The subgroup

TABLE II-Thyroid function in patients with lung cancer with low ard with normal T3 concentrations. Values are means $\pm S E$ of mean

\begin{tabular}{|c|c|c|c|c|}
\hline & $\begin{array}{c}\text { T3 } \\
(\mathrm{nmol} 1)\end{array}$ & $\begin{array}{c}\mathrm{T} 4 \\
(\mathrm{nmol} / \mathrm{l})\end{array}$ & FTI & $\underset{(\mathbf{m U} \mathbf{1})}{\mathrm{TSH}}$ \\
\hline $\begin{array}{l}\text { Low-T3 group }(n=45) \\
\text { Normal-T3 group } \\
(n=45)\end{array}$ & $\begin{array}{l}0.64=0.03 \\
1.49=0.06\end{array}$ & $\begin{array}{l}76 \cdot 9=2 \cdot 7 \\
96 \cdot 1=4 \cdot 2\end{array}$ & $\begin{array}{l}80 \cdot 4: 2 \cdot 98 \\
97 \cdot 2 \div 4 \cdot 7\end{array}$ & $\begin{array}{l}3 \cdot 1 \div 0 \cdot 4 \\
2 \cdot 8 \div 0 \cdot 4\end{array}$ \\
\hline Significance ( $P$ value $)$ & $<0.001$ & $<0.001$ & $<0.002$ & NS \\
\hline
\end{tabular}

NS $=$ Not significant.
Conversion: SI to traditional units-T3: $1 \mathrm{nmol} 1=0.065 \mu \mathrm{g} 100 \mathrm{ml} . \mathrm{T} 4: 1 \mathrm{nmol} / 1=$ 0.078 . $100 \mathrm{ml}$

TABLE III-Analysis of thyroid hormone concentrations in histologically reviewed lung cancer patients. Values are means $\pm S E$ of mean

\begin{tabular}{|c|c|c|c|c|c|}
\hline & No & $\underset{(\mathrm{nmol} / 1)}{\mathrm{T} 4}$ & FTI & $\begin{array}{c}\mathrm{T} 3 \\
(\mathrm{nmol} / \mathrm{l})\end{array}$ & $\mathrm{T} 4 \mathrm{~T} 3$ \\
\hline $\begin{array}{l}\text { Total group } \\
\text { Matched controls }\end{array}$ & $\begin{array}{l}55 \\
55\end{array}$ & $\begin{array}{l}98 \cdot 2 \div 3 \cdot 6^{*} \\
87 \cdot 7 \div 3 \cdot 1\end{array}$ & $\begin{array}{l}94 \cdot 4=3 \cdot 5 \\
86 \cdot 4=2 \cdot 9\end{array}$ & $\begin{array}{l}1.50 \div 0.07 \\
1.63 \div 0.05\end{array}$ & $\begin{array}{l}77 \cdot 3: 7 \cdot 0 \S \\
54 \cdot 9: 1.5\end{array}$ \\
\hline $\begin{array}{l}\text { Small cell anaplastic } \\
\text { (oat cell) }\end{array}$ & 16 & $104 \cdot 2=7 \cdot 0^{+}$ & $100 \cdot 4=6 \cdot 2_{+}^{+}$ & $1 \cdot 49: 0 \cdot 11$ & $73 \cdot 7 \div 5 \cdot 3 \S$ \\
\hline $\begin{array}{l}\text { Matched controls } \\
\text { Large cell anaplastic } \\
\text { Matched controls } \\
\text { Squamous } \\
\text { (epidermoid) }\end{array}$ & $\begin{array}{r}16 \\
9 \\
9 \\
28\end{array}$ & $\begin{array}{r}83 \cdot 8 \div 3 \cdot 9 \\
102 \cdot 6=8 \cdot 0 \\
90 \cdot 1=6 \cdot 0 \\
92 \cdot 3-5 \cdot 4\end{array}$ & $\begin{array}{l}79 \cdot 7=4 \cdot 0 \\
96 \cdot 4=6 \cdot 6 \\
93 \cdot 3=5 \cdot 7 \\
91 \cdot 0=5 \cdot 4\end{array}$ & $\begin{array}{l}1.65: 0.09 \\
1.30: 0 \cdot 2 \\
1.62: 0 \cdot 1 \\
1.54: 0 \cdot 09\end{array}$ & $\begin{array}{rl}52 \cdot 5 & 2 \cdot 8 \\
113 \cdot 7 & 3 \cdot 4 \\
56 \cdot 2 & 3 \cdot 5 \\
67 \cdot 6 & 6 \cdot 0\end{array}$ \\
\hline Matched controls & 28 & $88 \cdot 8 \div 5 \cdot 1$ & $87 \cdot 0: 4 \cdot 6$ & $1.60 \div 0.08$ & $55 \cdot 8 \doteq 2 \cdot 1$ \\
\hline
\end{tabular}

$* \mathrm{P}<0.05 v$ controls.

$+\mathrm{P}<0.02 v$ controls.

$+\mathrm{P}<0.01 v$ controls.

$\$ \mathrm{P}<0.002 v$ controls.

Conversion: SI to traditional units $-\mathrm{T} 3: 1 \mathrm{nmol} / 1=0.065 \mu \mathrm{g} / 100 \mathrm{ml}$. T4 $: 1 \mathrm{nmol} / 1=$ $0.078 \mu \mathrm{g} 100 \mathrm{ml}$ 
of 55 lung cancer patients who were studied histologically showed a pattern of thyroid hormone concentrations similar to that of the total lung cancer group (table III). Patients with all the histological types of lung cancer had a higher T4 T3 ratio than did the controls, though the difference reached statistical significance only in the small-cell anaplastic group.

Relationship of thyroid hormone concentrations to extrathoracic metastases-There was no significant difference in thyroid hormone or TSH concentrations between the 103 patients with apparently localised disease and the 101 with extrathoracic metastases.

\section{Discussion}

The results of our study indicate that in newly diagnosed patients with lung cancer the overall prevalence of previously unrecognised primary hypothyroidism is $1.5^{\circ}$ " and of minor degrees of hypothyroidism (defined on the basis of raised TSH concentrations) $3{ }^{\circ}{ }_{0}$. This is not appreciably different from the prevalence that might be expected in a group of similar age and sex composition without malignant disease, for Tunbridge $e a^{12}$ reported the overall prevalence of spontaneous overt hypothyroidism in an adult population in north-east England as between 0.8 and $1.1{ }^{\circ}{ }_{0}$, with minor degrees of hypothyroidism in $7.5^{\circ}{ }_{0}$ of women and $2 \cdot 8^{\circ}{ }_{0}$ of men. Primary hypothyroidism occurred only in elderly women and is likely to be due to coincident autoimmune thyroid disease. Four patients $\left(2^{\circ}{ }^{\prime \prime}\right)$ showed the biochemical pattern of secondary hypothyroidism, though none had clinical evidence of hypopituitarism or metastatic disease in the hypothalamus or pituitary.

The absence of any patients with biochemical or clinical evidence of hyperthyroidism (the prevalence of which is less than $0.5^{\circ}{ }_{0}$ ) confirms the rarity of its association with lung cancer. Increased TSH-like immunoactivity was associated not with increased thyroid activity but rather with the thyroid hormone pattern of subclinical hypothyroidism.

We observed a marginally raised T4 concentration or FTI, or both, in about $4^{\circ}{ }^{\circ}$ of euthyroid lung cancer patients aged between 54 and 82 ; but a small increase in T4 concentration may occur in euthyroid elderly people and our finding may not reflect any condition needing treatment. ${ }^{13}$ This interpretation is supported by the finding of low normal $\mathrm{T} 3$ concentrations in these patients (mean $1.49 \mathrm{nmol} / 1(0.097 \mu \mathrm{g} / 100 \mathrm{ml}))$.

The most striking abnormality of thyroid hormone metabolism was a biochemical syndrome of low T3 concentration, normal T4 concentration and FTI, and normal or slightly raised reverse T3 concentration, which has been described in various acute and chronic illnesses (the "sick euthyroid" or "low T3" syndrome). ${ }^{1+-16}$ This has been reported in patients with disseminated malignancy, ${ }^{14}$ though neither of the patients with carcinoma of the lung described by Bermudez and colleagues ${ }^{15}$ had a low T3 concentration. Our data suggest that the syndrome was not solely related to severity of illness as most of the patients with lung cancer were ambulant and attending a chest clinic for the first time, whereas many of the control patients had advanced chronic lung disease. Moreover, lung cancer apparently restricted to the thorax may be associated with the syndrome, as no significant differences were found between patients with and without extrathoracic metastases. While undetected metastatic disease cannot be excluded in patients thought to have disease confined to the thorax, even localised lung cancer probably exerts a powerful effect on T4 metabolism. There is, however, no evidence that such patients with low T3 concentrations are clinically hypothyroid, and our patients with lung cancer had TSH concentrations that were similar and within the normal range whether or not their $\mathrm{T} 3$ concentrations were subnormal. Moreover, patients with the low-T3 syndrome show a normal response to TRH. ${ }^{16}$

The low T3 concentrations appear to be due to inhibition of the rate of extrathyroidal $5^{\prime}$-monodeiodination of $\mathrm{T} 4$ to metabolically active $\mathrm{T} 3$ and an increased rate of 5-deiodination of $\mathrm{T} 4$ to metabolically inactive reverse $\mathrm{T} 3$, rather than to an increased rate of T3 catabolism or selective decrease in thyroidal T3 secretion. ${ }^{1-}$ Analysis of the data on the patients studied histologically suggests that this pattern is more definite in the anaplastic tumour group than in the squamous-cell group. Small-cell anaplastic tumours are biochemically active since they are particularly associated with ectopic hormone production and increased corticosteroid excretion. ${ }^{1 \times 19}$ Possibly such tumours secrete substances that influence the pathway of T4 monodeiodination either directly or via corticosteroids, as these alter the pathway of T4 metabolism in favour of reverse T3.20 Alternatively, the altered metabolic pathway may be a relatively non-specific effect of illness that is especially pronounced in patients with anaplastic tumours.

Whatever the mechanism, low T3 concentrations and an increased $\mathrm{T} 4 \mathrm{~T} 3$ ratio may have implications for prognosis and treatment since low T3 concentrations may induce changes in the ratio of $5 \%$ to $5 x$ corticosteroids (androsterone/aetiocholanolone). In anorexia nervosa, for example, the low-T3 syndrome is associated with an increased $5 / 5 x$ ratio, which is reversed by administering exogenous T3. ${ }^{21}$ An increased $5 \beta / 5 \alpha$ ratio is a poor prognostic sign in lung cancer,"-2 and indeed our patients with low T3 levels had a poor short-term prognosisabout twice as many of these patients died within six months as of the matched group with normal T3 concentrations. Clearly more detailed follow-up studies of these patients, with direct measurements of thyroid hormone and relevant corticosteroid concentrations, are required to test this hypothesis.

We are grateful to the Cancer Research Campaign for financial support. We thank Dr L G S Rao for helpful discussion and Dr D C Evered for prepublication data. Reagents for TSH assay were kindly made available by the National Institutes of Health, USA.

\section{References}

${ }^{1}$ Beatson, G T, Lancet, 1896, 2, 104.

Spencer, J G C, British Fournal of Cancer, 1954, 8, 393.

British Medical fournal, 1974, 1, 472.

${ }^{4}$ Lancet, 1974, 1, 908.

Moossa, A R, Price Evans, D A, and Brewer, A C, Annals of the Royal College of Surgeons of England, 1973, 53, 178.

${ }^{6}$ De Gennes, L, Bricaire, H, and Leprat, J, Presse Médicale, 1962, 70, 2137.

' Rassam. J W, and Anderson, G, Thorax, 1975, 30, 86.

* World Health Organisation, Histological Typing of Lung Tumours. Geneva, WHO, 1967.

${ }^{9}$ Challand, G S, Ratcliffe, W A, and Ratcliffe, J G, Clinica Chimica Acta, 1975, 60, 25.

${ }^{10}$ Ratcliffe, W A, Marshall, J, and Ratcliffe, J G, Clinical Endocrinology, 1976, 5, 631.

${ }^{11}$ Hall, R, Amos, J, and Ormston, B J, British Medical fournal, 1971, 1, 582.

12 Tunbridge, W M G, et al, Clinical Endocrinology. In press.

${ }^{13}$ Britton, K E, et al, Lancet, 1975, 2, 141.

${ }^{14}$ Carter, J N, et al, Lancet, 1974, 2, 971.

${ }^{15}$ Bermudez, F, Surks, M I, and Oppenheimer, J H, fournal of Clinical Endocrinology, 1975, 41, 27.

${ }^{16}$ McLarty, D G, et al, Lancet, 1975, 2, 275.

17 Carter, J N, et al, Clinical Endocrinology, 1976, 5, 587.

${ }_{18}$ Rees, L H, and Ratcliffe, J G, Clinical Endocrinology, 1974, 3, 263.

19 Amatruda, T T, and Upton, G V, Annals of the New York Academy of Sciences, 1974, 230, 168.

${ }^{20}$ Burr, W A, et al, Lancet, 1976, 2, 1277.

${ }^{21}$ Bradlow, H L, et al, fournal of Clinical Endocrinology, 1976, 43, 571.

22 Rao, L G S, Lancet, 1970, 2, 441.

(Accepted 10 November 1977) 